\title{
THYROXINE-BINDING CAPACITY OF SERUM IN NORMAL MAN ${ }^{1}$
}

\author{
By JACOB ROBBINS 2 AND J. E. RALL 3 \\ (From the Sloan Kettering Institute for Cancer Research, Memorial Center for Cancer and \\ Allied Diseases, New York, N. Y.)
}

(Submitted for publication February 18, 1955 ; accepted April 20, 1955)

The presence of a specific thyroxine-binding protein in human serum was first suggested from studies by Gordon, Gross, O’Connor, and PittRivers (1), employing zone electrophoresis. Although such a protein has not yet been isolated, certain of its properties may be determined in unfractionated serum when the specific protein has been labeled with thyroxine- $\mathrm{I}^{131}$. In this way, it has been demonstrated that this protein has: 1) an electrophoretic mobility at $\mathrm{pH} 8.6(1-5)$, as well as at $\mathrm{pH} 6$ and 7.6 (5), intermediate between alpha-1 and alpha-2 globulins, 2) an electrophoretic mobility at $\mathrm{pH} 4.5$ similar to the "M-2 proteins," or alpha-2 glycoproteins, of serum (6), and 3) a sedimentation rate in the ultracentrifuge of approximately 3.3 Svedbergs (7).

In the present study, this technique has been applied to an investigation of the thyroxine-binding capacity of this specific protein.

\section{MATERIALS AND METHODS}

Serum was obtained after an overnight fast from six normal young adults-three men ${ }^{4}$ and three women; from one young woman with Graves' disease; and from

1 This work was supported by a grant from the Damon Runyon Memorial Fund for Cancer Research, a grant from the American Cancer Society, and a contract with the Atomic Energy Commission, No. AT (30-1)-910.

2 Present address : National Institute of Arthritis and Metabolic Diseases, National. Institutes of Health, Bethesda, Maryland.

3 Alfred P. Sloan Foundation Scholar.

4 One subject had ulcerative colitis, and had received a trial course of diiodoquine therapy, which had been stopped 3 months before the serum was obtained. This was discovered in retrospect, when a serum protein-bound iodine value of 19 micrograms per $100 \mathrm{ml}$. was found. The serum thyroxine level which was used in the calculations was determined by a repeat iodine determination on serum obtained 21/2 months later, at which time the serum protein-bound iodine was 4.3 micrograms per 100 $\mathrm{ml}$. The data of this experiment are included since they did not differ significantly from those in other experiments. one young man with cretinism, who was being maintained in a euthyroid state by triiodothyronine administration. The serum was stored in the frozen state until used.

Synthetic L-thyroxine, labeled with $I^{131}, 5$ was diluted with appropriate quantities of $n$-butanol, and evaporated to dryness in vacuo without heating. Serum was then added, so as to produce a wide range of thyroxine concentrations in the serum from each subject. The serumthyroxine mixtures were allowed to stand for 15 to 20 hours at $4^{\circ} \mathrm{C}$. and then were stored in the frozen state. The concentration of thyroxine in the serum-thyroxine mixtures was determined by analysis of total iodine in the synthetic thyroxine preparations, and of proteinbound iodine in the original serum, by a modification of the method of Barker (8). (It was assumed that all of the iodine so measured was in the form of thyroxine.) Recovery of labeled thyroxine after drying was assessed by comparing the radioactivity in each serum-thyroxine mixture with that in a portion of the original butanol solution. These measurements were performed with a well-type scintillation counter. The recoveries were usually between 85 and 100 per cent, but occasional values as low as 30 per cent were obtained. The latter occurred at very low dilution of the original thyroxine solution, and may be related to the fact that this original material contained a greater solid residue after evaporation than did the butanol added as diluent. Thus, this factor was present only at the highest thyroxine concentrations.

A total of 9 experiments were performed on the six normal sera, using 6 separate batches of thyroxine-I131. In all, 64 individual determinations of thyroxine-binding were done. The endogenous serum thyroxine levels varied from .05 to .08 microgram per $\mathrm{ml}$., and the total thyroxine levels varied from .06 to 8.8 micrograms per $\mathrm{ml}$.

In order to obtain data for serum thyroxine levels lower than normal, the serum from a cretin was employed. This patient had been maintained on daily doses of $0.2 \mathrm{mg}$. of triiodothyronine for the preceding 2 months, so that his serum protein-bound iodine level was low

${ }^{5}$ L-thyroxine was obtained through the courtesy of Smith, Kline and French Laboratories, Philadelphia, Pa., and labeled with I131 by Abbott Laboratories, Oak Ridge, Tenn. These preparations were dissolved in n-butanol, and had specific activities of approximately 8 to 40 mc. per mg. In one instance, thyroxine-I131 was obtained in 50 per cent propylene glycol, and was added directly to the serum after appropriate dilution with water. 
(.009 microgram per $\mathrm{ml}$.) even though he was in a euthyroid state by all other laboratory and clinical criteria. For the purposes of calculation, the serum protein-bound iodine was considered to be thyroxine, although it was perhaps more likely triiodothyronine. In this serum, the total thyroxine level was adjusted to from .017 to 3.2 micrograms per $\mathrm{ml}$. If the endogenous serum iodine were neglected, only the lowest thyroxine values would be affected, and, even there, the general form of the results would be unaltered.

The serum from the hyperthyroid patient was used to evaluate the degree of exchange between endogenous serum thyroxine and added synthetic thyroxine (see Results).

The purity of the thyroxine- $\mathrm{I}^{131}$ preparations was evaluated by paper chromatography with techniques described elsewhere (4), except that a continuously recording counting rate meter was used (see below). Each batch was chromatographed in a $n$-butanol-2,4-dioxane $-2 \mathrm{~N}$ ammonia system (9), and some in a n-butanolprimary amyl alcohol-2N ammonia system (4) as well. In the 7 batches of labeled thyroxine used in this study, thyroxine-I ${ }^{131}$ comprised from 72 to 91 per cent (mean = 83 per cent) of the total radioactivity. From 2 to 7 per cent of the total radioactivity behaved like iodide; and the remainder was due to one or more contaminants of unknown nature, with $\mathrm{Rf}$ values higher than thyroxine. These contaminants did not appear to be triiodothyronine or diiodothyronine. Chromatographic analyses of the thyroxine-serum mixtures ${ }^{6}$ were identical with those of the original butanol solutions, with the exception of from 1 to 4 per cent immobile radioiodine in the former.

The thyroxine concentration measurement was not corrected for this impurity factor, since the behavior of the major contaminants with regard to protein-binding has not been determined. In two experiments with normal sera, and in one with hyperthyroid serum, thyroxineI131 was kept constant, while the total thyroxine was varied by adding unlabeled L-thyroxine. The purity of this material was 97 per cent, according to analyses in the Smith, Kline, and French Laboratories. ${ }^{\text {? }}$

Each serum-thyroxine mixture was studied by zone electrophoresis in filter paper at $\mathrm{pH} 8.6$ (barbital buffer, ionic strength 0.1 ), by techniques described elsewhere $(4,6)$. The distribution of radioiodine among the various serum protein components was determined by counting the strips with a thin mica-window Geiger-Mueller tube and a continuously recording counting rate meter. The counting aperture was a $1 \times 2.7 \mathrm{~cm}$. rectangle. Since the area under the curves obtained with the counting apparatus was proportional to the quantity of radioactivity on the paper strip, the amount of $I^{131}$ in the protein fractions could be measured by planimetry. In 2 experiments, the strips were stained prior to counting. Since this procedure resulted in a slight under-

6 The thyroxine-serum mixtures were applied directly to the paper strips without prior extraction (4).

7 The authors wish to thank Dr. A. Heming of the Smith, Kline, and French Laboratories for these analyses. estimation (approximately 10 per cent) of radioiodine in alpha globulin, due to a relatively greater loss of this component during washing, all subsequent radioiodine measurements were performed prior to staining.

In the results which follow, total serum thyroxine concentration represents the sum of endogenous and added thyroxine. Thyroxine bound to alpha globulin, or to albumin, was calculated as the product of total serum thyroxine and the fraction of total serum radioiodine associated with the protein in the electrophoretic analyses.

\section{RESULTS}

Figure 1 illustrates the electrophoretic patterns obtained at various serum thyroxine levels. At a normal level ( 0.10 microgram per $\mathrm{ml}$.), the major portion of the thyroxine- $\mathrm{I}^{131}$ has a mobility intermediate between alpha- 1 and alpha- 2 globulin, but overlaps both of these components. A smaller portion coincides with albumin, and a still smaller amount, with the other protein fractions. At least part of the radioiodine associated with the beta and gamma globulins probably represents adsorption of albumin or alpha globulin radioiodine on the paper, as suggested by the presence of radioiodine between the point of application and

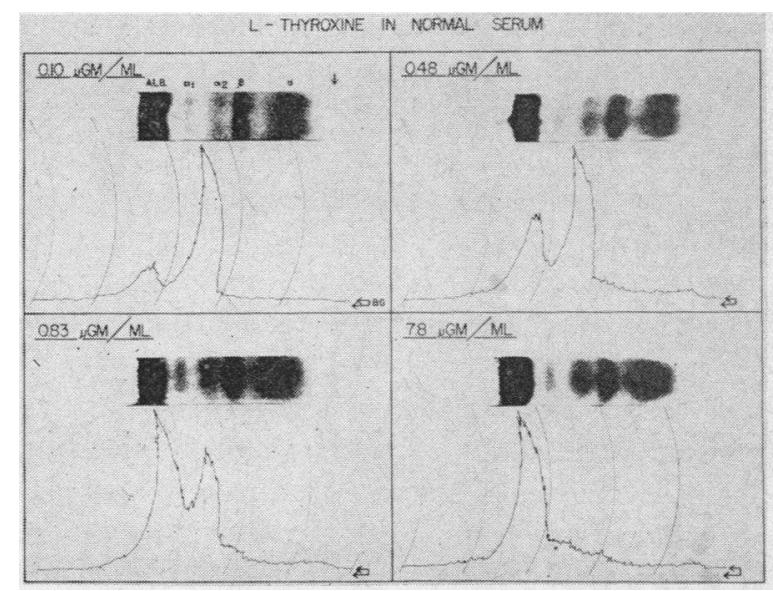

Fig. 1. The Effect of Increasing Concentrations of Serum Thyroxine on the Electrophoretic DisTRIBUTION OF THYROXINE-I'131

Synthetic thyroxine-I131 was added to normal serum, producing the total serum thyroxine levels indicated in the figure. In each instance, a continuous recording of the radioactivity on the paper strip (lower portion), is compared with the stained protein components on the same paper strip (upper portion). The single arrow denotes the point of application of the serum to the paper, and the double arrow, labeled "BG," represents background radioactivity. (Buffer: sodium barbital, $\mathrm{pH}$ 8.6, ionic strength 0.1 .) 


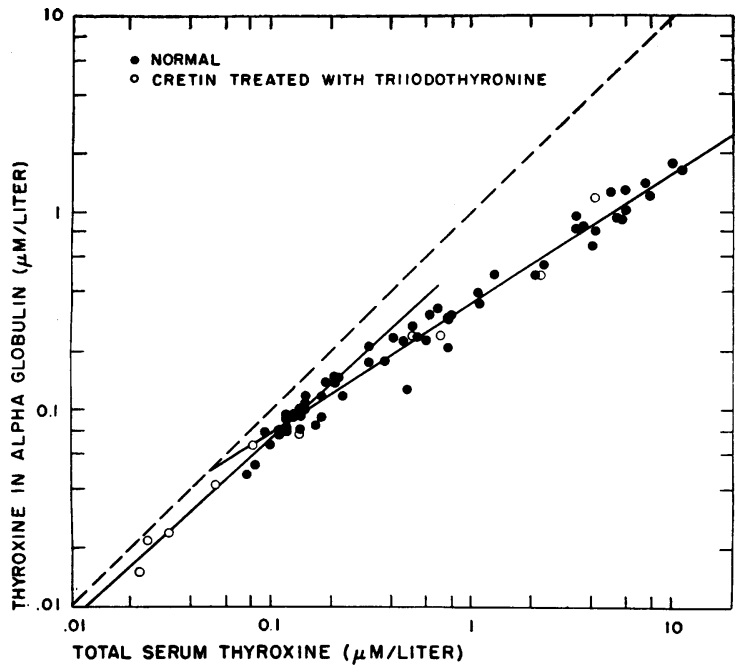

Fig. 2. The Concentration of Alpha GlobulinBound Thyroxine at Increasing Concentrations of Total Serum Thyroxine

- = normals, $\bigcirc=$ cretin treated with triiodothyronine. See text for the procedure by which the solid lines were fitted to the experimental data. The broken line represents 100 per cent binding of serum thyroxine to alpha globulin.

the first protein band. A small band of radioiodine also is present with a mobility just faster than albumin. This is thought to represent an impurity in the thyroxine- $\mathrm{I}^{131}$ preparations, since it has not been observed in sera in which thyroxine has been labeled by endogenous synthesis.

As the thyroxine content of the serum is increased, thyroxine- $\mathrm{I}^{131}$ becomes increasingly associated with albumin. The proportion in the alpha globulin area becomes less, while that in the beta and gamma globulin areas, as well as that in front of albumin, remains relatively constant. In some experiments at very high thyroxine concentrations, larger amounts of radioiodine (15 to 35 per cent of total $\mathrm{I}^{131}$ ) were found in the gamma globulin, area, and, especially, in the form of a rather sharp band at the point of application. This appeared to represent thyroxine displaced from albumin during electrophoresis, since in these experiments the albumin thyroxine contents were somewhat lower. Free thyroxine would be expected to behave in this way (1).

Although an excessive proportion of immobile plus gamma globulin thyroxine- $\mathrm{I}^{131}$ (more than 15 per cent of total $\mathrm{I}^{131}$ ) was found in only 6 of the 12 experiments, other evidence was sought with regard to the possibility of incomplete protein-binding at high thyroxine levels. Analysis in the ultracentrifuge partition cell ${ }^{8}(7)$ indicated, however, that essentially all of the added thyroxine was bound to protein at even the highest thyroxine concentrations. The excessive immobile plus gamma globulin thyroxine- $\mathrm{I}^{131} \mathrm{did}$, therefore, appear to result from displacement of thyroxine from protein-presumably albumin.

Over the normal range of serum thyroxine concentration (.059 to 0.12 microgram per ml., or .076 to 0.15 micromole per liter), the values for per cent of total radioiodine in alpha globulin varied in an apparently random fashion between the limits of about 60 and 80 per cent. At thyroxine levels greater than 0.27 microgram per ml. ( 0.35 micromole per liter), all of the values were below 60 per cent and fell to a minimum of 14 per cent at the highest thyroxine levels tested. The exact point of transition, which would reflect that concentration of thyroxine at which the TBP is saturated, could not, however, be delineated from a plot of per cent of $\mathrm{I}^{131}$ in alpha globulin versus total serum thyroxine. At thyroxine levels below the normal range the per cent in alpha globulin was somewhat higher than in the normal range, but these values were all obtained in a single abnormal individual, and the low levels of radioactivity in these thyroxine-serum mixtures made the electrophoretic analyses less accurate. A definite radioactive peak in albumin was, however, present at even the lowest concentration.

In Figure 2, the concentration of thyroxine in alpha globulin in the normal sera, and in the cretin under triiodothyronine therapy, are plotted against total serum thyroxine on logarithmic coordinates. The data presented are not classified according to the individual experiments (see Materials and Methods), since there appeared to be no significant variation between the various sera or batches of thyroxine. The serum from the cretin, however, is distinguished from the normals. It is apparent that the concentration of thyroxine in alpha globulin continues to increase throughout the range employed. The data, however, appear to fall into two linear components.

${ }^{8}$ The authors are indebted to Dr. Mary L. Petermann, of the Sloan Kettering Institute, New York, N. Y., for these determinations. 
TABLE I

Statistical evaluation of data in figure 2

\begin{tabular}{|c|c|c|c|c|c|c|c|}
\hline \multirow[b]{2}{*}{ Grouping } & \multirow{2}{*}{$\begin{array}{l}\text { Separation } \\
\text { point-- } \\
\text { Total serum } \\
\text { thyroxine }\end{array}$} & \multirow{2}{*}{$\begin{array}{l}\text { No. in } \\
\text { lower } \\
\text { group }\end{array}$} & \multirow{2}{*}{$\begin{array}{l}\text { No. in } \\
\text { upper } \\
\text { group }\end{array}$} & \multirow[b]{2}{*}{ Equations for lines } & \multirow{2}{*}{$\begin{array}{l}\text { Intersection } \\
\text { value } \\
\text { Total serum } \\
\text { thyroxine }\end{array}$} & \multicolumn{2}{|c|}{$\begin{array}{l}.05 \text { Confidence limits } \\
\text { of intersection value }\end{array}$} \\
\hline & & & & & & Lower & Upper \\
\hline $1 \mathrm{st}$ & $\begin{array}{l}(\mu m / L .) \\
.250\end{array}$ & 34 & 40 & $\begin{array}{l}\log Y=.645 \log X-.4526 \\
\log Y=.895 \log X-.2576\end{array}$ & $\begin{array}{l}(\mu m / L .) \\
.166\end{array}$ & $\begin{array}{l}(\mu m / L .) \\
.0342\end{array}$ & $\begin{array}{l}(\mu m / L .) \\
.600\end{array}$ \\
\hline 2 nd & .166 & 26 & 48 & $\begin{array}{l}\log Y=.647 \log X-.4533 \\
\log Y=.927 \log X-.2182\end{array}$ & .145 & .0947 & .241 \\
\hline $3 \mathrm{rd}$ & .145 & 23 & 51 & $\begin{array}{l}\log Y=.643 \log X-.4799 \\
\log Y=.916 \log X-.2326\end{array}$ & .124 & .104 & .290 \\
\hline 4th & .124 & 15 & 59 & $\begin{array}{l}\log Y=.651 \log X-.4546 \\
\log Y=.942 \log X-.1981\end{array}$ & .132 & .0724 & .852 \\
\hline
\end{tabular}

These two groups were divided arbitrarily at a total serum thyroxine level of 0.25 micromole per liter, and the data for each section were fitted, by least squares, to the best straight line having the form $\log \mathrm{Y}=\mathrm{A}+\mathrm{B} \log \mathrm{X}$ (where $\mathrm{Y}=$ thyroxine concentration in alpha globulin, $\mathrm{X}=$ total serum thyroxine concentration). These lines intersected at a total serum thyroxine concentration of 0.166 micromole per liter. The points were then regrouped according to this value, and the process of fitting the data to two straight lines were repeated. Two additional regroupings were done on the basis of the new intersections. The intersections and the 95 per cent confidence levels of the total serum thyroxine values of the intersections are recorded in Table I (10). This method of successive approximation removed the main subjective portion of the statistical treatment. The 95 per cent confidence level of the second intersection, measured by $\mathrm{X}$, lay between .0947 and 0.241 micromole per liter. It seems apparent from Table I that groupings 3 and 4 did not improve the error of the intersection, and values from grouping 2 are most reliable. This grouping, it may be noted, did not rely heavily upon the data obtained in the cretin.

These values for total serum thyroxine concentration (.0947 and 0.241 micromole per liter), correspond to .0736 and 0.187 microgram of thyroxine per $\mathrm{ml}$, and to 4.82 and 12.3 micrograms of iodine per $100 \mathrm{ml}$. This is to be compared with the normal serum protein-bound iodine level of 4 to 8 micrograms per $100 \mathrm{ml}$.

In Figure 3, the concentration of thyroxine in albumin is plotted against total serum thyroxine on logarithmic coordinates. For those experiments in which more than 15 per cent of the total radioactivity was present in the gamma globulin area and at the origin of the paper strips (see above), an approximate correction for thyroxine displaced from albumin was provided by adding to the observed radioiodine in albumin that amount in gamma globulin plus origin which was in excess of 10 per cent. A total of 12 points in Figure 3 were corrected in this manner, and 8 of these were at total serum thyroxine levels greater than 1.0 micromole per liter. There again

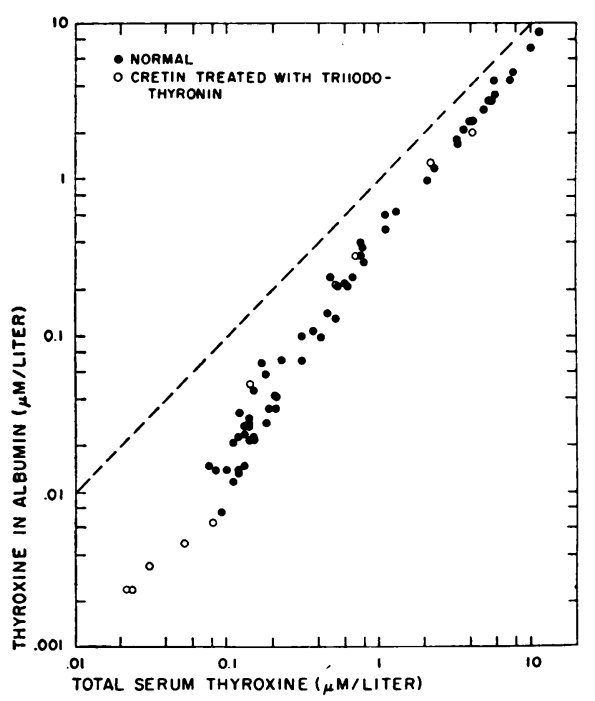

Fig. 3. The Concentration of Albumin-Bound Thyroxine at Increasing Concentrations of Total Serum Thyroxine

- = normals. $\bigcirc=$ cretin treated with triiodothyronine. The broken line represents 100 per cent binding of serum thyroxine to albumin. 


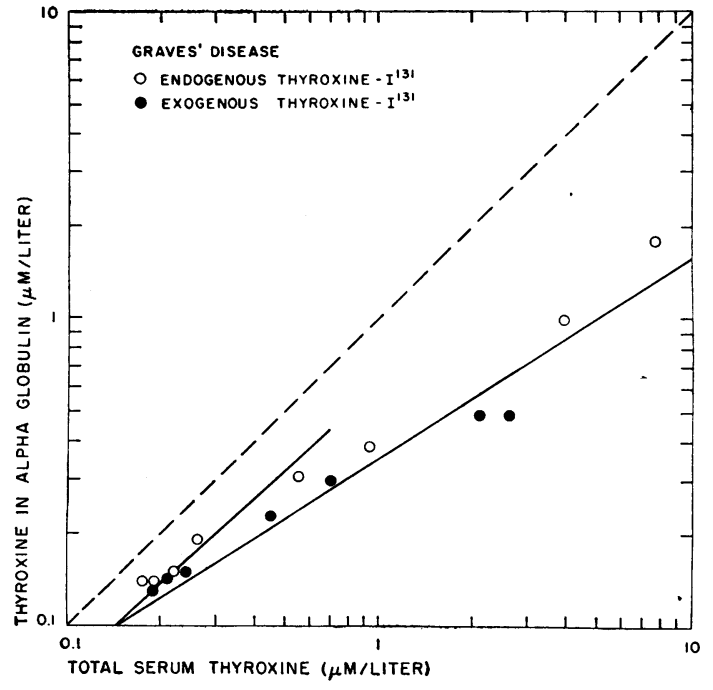

Fig. 4. A Comparison of Endogenously Labeled and Exogenously Labeled Thyroxine in the Same SERUM

$\mathrm{O}=$ endogenously labeled thyroxine. $\quad \bullet=$ exogenously labeled thyroxine. The lines are identical with those in Figure 2. The serum was obtained 48 hours after radioiodine therapy in a patient with Graves' disease. See text for details.

appear to be two components defined by these data, but the slopes differ so little that it is impossible to be sure of this and no statistical treatment was attempted.

The data for thyroxine in beta and gamma globulins have not been subjected to analysis, inasmuch as they are likely to be in considerable error due to adsorption of albumin-thyroxine, and possibly alpha globulin-thyroxine, on the paper in these areas. Experiments with purified bovine gamma globulin $(11,12)$ have indicated little or no binding of thyroxine.

In the calculations described thus far, it has been implied that equilibrium had been reached between the endogenous serum thyroxine and added thyroxine, and that there was free exchange between these. These assumptions were tested on the serum from a patient with hyperthyroidism. This patient had classical Graves' disease, complicated by auricular fibrillation, and her disease was under partial control with propylthiouracil. (The serum thyroxine level was 0.14 microgram per ml.) Serum was obtained 48 hours after the administration of a therapeutic dose of radioiodide. Chromatographic analysis of the serum $\mathrm{I}^{131}$ (see above) indicated that 82 per cent of it was in the form of thyroxine. Five per cent behaved like iodide, 3 per cent like triiodothyronine, and 10 per cent remained at the origin, and may have been thyroglobulin (13). The thyroxine content of this serum was altered by the addition of unlabeled synthetic L-thyroxine, otherwise following the procedure for the normal sera. A recovery of 100 per cent of the added thyroxine was assumed for the calculation of total thyroxine content.

A second portion of the same serum was stored until the endogenous radioiodine had decayed to negligible proportions. Thyroxine- $\mathrm{I}^{131}$ was then added in the same way as with the normal sera.

The results of these experiments are presented in Figure 4. It can be seen that the data are similar, whether the radioactive label was on the endogenous thyroxine or on the added thyroxine. (In the case of the two highest points obtained with exogenously labeled thyroxine the recovery of added radioiodine was 40 and 66 per cent.) These results appear to justify the assumptions of equilibrium and free exchange between endogenous and added thyroxine, and, in addition, indicate that natural and synthetic thyroxine behave similarly under the conditions employed. It is uncertain whether the values obtained with this single hyperthyroid serum differ significantly from those obtained with normals.

\section{DISCUSSION}

It is apparent from the data in Figure 1 that the specific thyroxine-binding protein $(\mathrm{TBP})^{9}$ has a limited capacity to combine with excess quantities of thyroxine added to serum. Similar findings have been reported by Albright, Larson, and Deiss (14), and by Horst (15). Evaluation of the thyroxine-binding capacity of this protein, however, is beset with certain difficulties. In contrast to iron-binding phenomena in serum (16), for example, when the TBP has become saturated, binding of thyroxine to other serum proteins, notably to albumin, occurs. With the techniques

9 The possibility exists that the specific thyroxinebinding protein referred to throughout this paper may in fact be a mixture of proteins. If such were the case, the term "thyroxine-binding protein" would more properly be described as the "thyroxine-binding sites" which are important at low serum thyroxine concentration. 
employed in the present study, it has not been possible to isolate TBP from the other alpha globulins. In addition, it has been shown (17) that albumin (and thus any thyroxine which is bound to albumin), is adsorbed to the paper in the path of albumin migration.

It will be evident that the binding between thyroxine and TBP could not be evaluated in the usual manner (18), as has been done in the case of thyroxine and bovine serum albumin by Lein (19). In the present experiments, neither the concentration of TBP nor the concentration of unbound thyroxine were known, and purified TBP has not been available.

The use of a $\log$-log function to describe the relationship of total serum thyroxine to thyroxine in alpha globulin was employed because it was the simplest function which fit the experimental data. This treatment lent itself to statistical analysis, and thus was of value, in the accompanying paper (20), as a basis for comparing the effects of various thyroxine analogues on thyroxine-binding in serum. A $\log$-log relationship as a means of describing protein binding, although sometimes used, is of questionable physical significance with regard to the present data, and at very high or very low concentration of thyroxine, patently fallacious.

The occurrence of a shift in the proportions of thyroxine in the alpha globulin and albumin areas might be taken as an indication of saturation, or of beginning saturation, of the TBP. This takes place at a serum thyroxine level approximately 2 to 3 times normal, at which point the value for thyroxine in alpha globulin is 60 to 80 per cent of the total serum thyroxine. The corresponding values for the intersection of the two components in Figure 2 are considerably lower, but their significance with respect to the thyroxine-binding capacity of TBP are problematical. The values by both criteria are lower than the thyroxinebinding capacity of TBP estimated by Albright, Larson, and Deiss (14) for normal serum. While their value of 0.4 to $0.5 \mathrm{microgram}$ per $\mathrm{ml}$. for thyroxine in alpha globulin at saturation was based upon different criteria, it is to be noted that they assumed, probably incorrectly, that all of the endogenous thyroxine remained fixed to TBP during the analyses. When their data are recalculated, assuming equilibrium between endo- genous and exogenous thyroxine, and an endogenous thyroxine level of 0.1 microgram per $\mathrm{ml}$., the normal thyroxine-binding capacity of alpha globulin is approximately 0.3 microgram per $\mathrm{ml}$., and is closer to the value indicated by the present study.

In contrast to the findings of Albright, Larson, and Deiss (14), the concentration of thyroxine in alpha globulin in the present study did not reach a plateau, but continued to increase throughout the range of thyroxine levels examined. This increase might be due to the binding of thyroxine to secondary sites on the alpha globulins, possibly on TBP itself. It might also be due to albumin-bound thyroxine which becomes fixed to the paper in the alpha globulin area. Preliminary experiments (21) have indicated that the latter alternative plays an important part in this phenomenon. In this regard, it may be of significance that Albright, Larson, and Deiss employed a different type of filter paper than that used in the present experiments.

The results of the present experiments can be considered valid only for the particular techniques used. It has not been established whether these results may differ when the binding phenomena are observed at different $\mathrm{pH}$, in other buffers, or by techniques other than zone electrophoresis.

\section{SUM MARY}

The thyroxine-binding capacity of the specific thyroxine-binding protein (TBP) in normal serum has been studied by the use of thyroxine labeled with $\mathrm{I}^{131}$, and zone electrophoresis at $\mathrm{pH}$ 8.6. It has been shown that this protein has a limited capacity to bind thyroxine, but the measurement of the actual binding capacity was complicated by the fact that excess thyroxine is bound to other serum proteins, notably to albumin, and the fact that the TBP could not be isolated from the other alpha globulins. It appears likely, however, that saturation of TBP occurs at serum thyroxine levels at least 2 to 3 times normal.

\section{ACKNOWLEDGMENT}

The authors wish to express their thanks to Dr. Rulon W. Rawson for his most helpful interest throughout this work, to Miss Helen Hagopian for excellent technical assistance, and to Miss Jane Heslin for help in the statistical analyses. 


\section{REFERENCES}

1. Gordon, A. H., Gross, J., O'Connor, D., and PittRivers, R., Nature of the circulating thyroid hormone-plasma protein complex. Nature, 1952, 169, 19.

2. Winzler, R. J., and Notrica, S. R., Association of thyroxine with plasma proteins. Federation Proc., 1952, 11, 312.

3. Deiss, W. P., Albright, E. C., and Larson, F. C., A study of the nature of the circulating thyroid hormone in euthyroid and hyperthyroid subjects by use of paper electrophoresis. J. Clin. Invest., 1952, 31, 1000.

4. Robbins, J., and Rall, J. E., Zone electrophoresis in filter paper of serum I'131 after radioiodide administration. Proc. Soc. Exper. Biol. \& Med., 1952, 81, 530.

5. Horst, W., and Rösler, H., Der Transport des Hormonjods in menschlichen Serum untersucht mit Papier-elektrophorese und Radiojod. Klin. Wchnschr., 1953, 31, 13.

6. Robbins, J., Petermann, M. L., and Rall, J. E., Electrophoresis of the thyroxine-binding protein of serum at pH 4.5. J. Biol. Chem., 1955, 212, 403.

7. Petermann, M. L., Robbins, J., and Hamilton, M. G., Sedimentation of the thyroxine-binding protein of serum in the partition cell. J. Biol. Chem., 1954, 208, 369.

8. Barker, S. B., Determination of protein-bound iodine. J. Biol. Chem., 1948, 173, 715.

9. Gross, J., Leblond, C. P., Franklin, A. E., and Quastel, J. H., Presence of iodinated amino acids in unhydrolyzed thyroid and plasma. Science, 1950, $111,605$.

10. Fisher, R. A., Statistical Methods for Research Workers. 11th Edition, Edinburgh, Oliver and Boyd, 1950, p. 144.
11. Taurog, A., and Chaikoff, I. L., The nature of the circulating thyroid hormone. J. Biol. Chem., 1948, 176, 639.

12. Lein, A., The binding of thyroxin, diiodotyrosine and triiodothyronine by bovine serum proteins. Abstracts of papers, J. Am. Chem. Soc., March 1519,1953, p. 16 c.

13. Robbins, J., Thyroglobulin in serum after $\mathrm{I}^{131}$ therapy. I. Salting out. J. Biol. Chem., 1954, 208, 377.

14. Albright, E. C., Larson, F. C., and Deiss, W. P., Thyroxine binding capacity of serum alpha globulin in hypothyroid, euthyroid, and hyperthyroid subjects. J. Clin. Invest., 1955, 34, 44.

15. Horst, W., Neue Ergebnisse der Anwendung von J181 in Diagnostik und Therapie von Schilddrüsenerkrankungen. Strahlentherapie, 1954, 94, 169.

16. Horst, W., and Schäfer, K. H., Die Eisenbindung im Serum und in weiteren biologischen Flüssigkeiten, untersucht mit Papierelektrophorese und Radioeisen $\left(\mathrm{Fe}^{59}\right.$ und $\left.\mathrm{Fe}^{55}\right)$. Zugleich eine Neue Methode zur Beurteilung der Eisenbindungskapazität Biologischer Flüssigkeiten. Klin. Wchnschr., 1953, 31, 791.

17. Slater, R. J., and Kunkel, H. G., Filter paper electrophoresis with special reference to urinary proteins. J. Lab. \& Clin. Med., 1953, 41, 619.

18. Klotz, I. M., Protein interactions in Neurath, H., and Bailey, K., The Proteins. New York, Academic Press, Inc., 1953, vol. 1 B, p. 727.

19. Lein, A., Thyroxine binding by bovine serum albumin. Federation Proc., 1952, 11, 91.

20. Robbins, J., and Rall, J. E., Effects of triiodothyronine and other thyroxine analogues on thyroxine-binding in human serum. J. Clin. Invest., 1955, 34, 1331.

21. Robbins, J., Unpublished data. 